\title{
Acceptance of Neurology Telemedicine Technology in Emergency Department
}

\author{
Teresa W McNeil and Sajeesh Kumar* \\ Department of Health Informatics \& Information Management, USA
}

Submission: May 10, 2017; Published: May 30, 2017

"Corresponding author: Sajeesh Kumar, Department of Health Informatics \& Information Management, University of Tennessee Health Science Center, Memphis, TN, USA, Email: skumar10@uthsc.edu

Abstract

Introduction: Currently a significant shortage of trained neurologists exists in the country. In addition, there is an increasing need for neurologists due to an aging population, increase in the incident of neurologic diseases and an increasing demand for healthcare. The development of tele neurology technology has been shown to help address these problems.

Method: A survey of users of the telemedicine was conducted to access the end-user's perceived usefulness and ease of use of this technology. A descriptive research design was used to identify user acceptance of neurology telemedicine technology, VGo, used in the emergency department. The population surveyed was all practitioners working in the two emergency where the neurology telemedicine product VGo is used.

Results: The results of this survey clearly indicate that there is a difference in user perceived usefulness and ease of use of the telemedicine technology VGo based on the length of experience with the product.

Conclusion: The responses yields information on user's acceptance of the technology and reveals difference in perceptions of those with and without experience using the technology.

Keywords: Tele neurology, User acceptance, Emergency department

\section{Introduction}

Early intervention for diagnoses such as acute myocardial infarction (AMI) and acute ischemic stroke can mean life or death. A rapid response system in the form of neurology telemedicine, could potentially improve patient outcomes for these and other neurological diagnoses [1]. Telemedicine for strokes helps to overcome some of the shortcomings of regional hospitals by providing the expertise of established stroke center on demand and within minutes [2,3]. This potentially could result in improved patient outcomes. In a study of neurology departments representing the top 50 hospitals ranked by U. S. News and World Report, 63\% rated telemedicine as equivalent to in-person care [4]. Telemedicine is increasingly viewed as a means to improve health care delivery and the telemedicine industry is projected to be an $\$ 18$ billion global market by 2015 [4]. The biggest benefit would be to the patient by having access to the specialty treatment needed in a timely manner to affect the outcome of their condition. In a 2013 study management by neurologists of disorders such as Parkinson disease has been shown to reduce hospitalizations and health care expenditures [3]. These studies demonstrate the importance of having specialty trained neurologist available to treat patients and can potentially improve patient outcomes, safety and reduce costs.

Another reason to demonstrate the benefits of the use of neurology telemedicine is a projected increase in the shortfall of neurologist to $19 \%$ by 2025 [3]. It is predicted that there will be an increase in neurology patients in the emergency department and due to the lack of neurological specialists and training could result in worse outcomes [3]. Telemedicine is being used to help offset this potential crisis. In a 1997 study of telemedicine used by East Carolina University School of Medicine, where there are serious shortages of health care providers it was noted that telemedicine is helping to overcome this shortage by making specialty medical consultations available to people in rural communities [5]. In the study of the 50 top rated hospitals, it was reported that $85 \%$ of neurology departments in those hospitals plan to provide telemedicine [4].

A key component to positive patient outcomes, and often an overlooked one, is user acceptance and use of the technology. Many components can influence user perceptions and acceptance. 
Among some of the lessons learned during implementation of the East Carolina University School of Medicine telemedicine program, which identified a clear need for a high level of teamwork among all network participants, good interpersonal communication is especially important. In addition to staffing, technical requirements was a consideration, again to ensure the technology was working each time it was required for use. A final lesson learned was one of scheduling, because they had multiple sites with limited resources to utilize the technology. For an emergency department, scheduling of resources would be impossible, so dedicated technology would be a requirement. A final recommendation of this study was that telemedicine must become fully integrated with traditional medical information systems to be more effective [5].

The purpose of current study is to evaluate the effectiveness of using neurology telemedicine in the emergency department and specifically identify barriers that may exist in the form of user acceptance of neurology telemedicine technology that could affect clinical outcomes. Are there barriers created by user acceptance of the technology? Do the users perceive that the technology is useful and easy to use? This information could then be utilized by other organizations working to develop a neurology telemedicine program in their facilities to reference as lessons learned and address these barriers prior to implementation.

\section{Method}

This study is modeled after Davis's Technology Acceptance Model (TAM), whichprovides a valid and reliable measure that predicts the acceptance or adoption of new technologies by end-users [6]. The participants of this study are practitioners from Hunt Regional Medical Center and the survey specifically focused on their perceptions of a neurology telemedicine product recently launched in the emergency department called VGo.

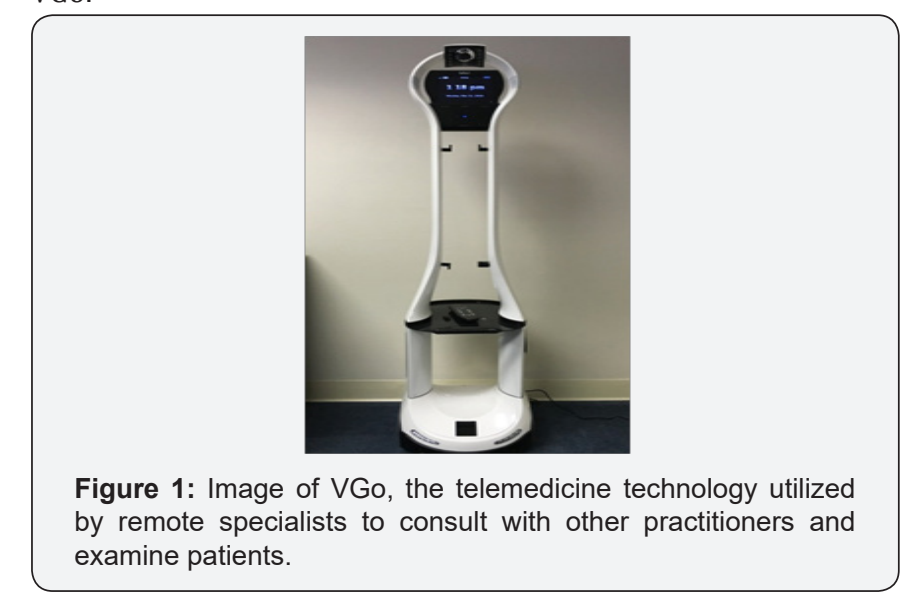

VGo is a slender 4-foot tall robot on wheels that works via remote control using a laptop or iPad to control (Figure 1). The VGo technology works with a two-way video and audio communication, allowing physicians to consult with other practitioners and examine patients. Physicians can control the movement of the VGo with their computer mouse or keyboard, tilting and zooming the camera that sits atop its spherical head as they examine a patient, or move from one location to another.

A descriptive research design was used to identify user acceptance of neurology telemedicine technology, VGo, used in the emergency department at Hunt Regional Medical Center. The population surveyed was all practitioners working in the two emergency departments of Hunt Regional Medical Center where the neurology telemedicine product VGo is used. The paper survey was designed and reviewed by a multidisciplinary team at the facility. The tool was approved by the facilities Compliance Committee and the Internal Review Board at the University of Tennessee Health Science Center.

\section{Results}

A total of 40 surveys were distributed, the total responses from both emergency departments were 20 for an overall response rate of $50 \%$. The following graphs and tables provide the basic information about the respondents to the survey (Figure 2).

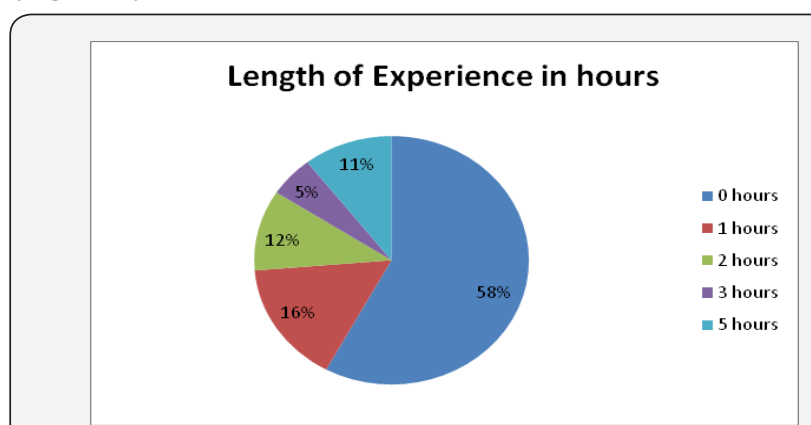

Figure 2: Length of Tele neurology experience in hours

\section{Discussion}

Thirty-one percent (31\%) of the respondents were RN's while 26\% were MD's and another $26 \%$ fell into the other category. Seventy-nine percent $(79 \%)$ of the respondents were between 30-60 years old. Thirty-two percent (32\%) were 30$40,21 \%$ were $40-50$ and $26 \%$ were $50-60$. The gender of the respondents was almost a 50/50 split, with $47 \%$ female and $53 \%$ male.

Forty-two percent (42\%) of respondents indicated having experience in using VGo while $58 \%$ reported having no experience in using the product. Of those reporting having experience with using VGo, $15.8 \%$ had 1 hour of experience, $10.5 \%$ had 2 hours of experience, $5.3 \%$ had 3 hours of experience and $10.5 \%$ had 5 hours of experience. The first set of six questions was designed to access the user's acceptability of the VGo product.

Table $1 \& 2$ displays the responses to each of the 12 questions from the eleven respondents with no experience using VGo. The questions are grouped by the user acceptability questions and 
ease of use questions. For the respondents with no experience over half of responses to all questions were neutral, ranging from $54.5 \%$ to $81.8 \%$. Of the remaining responses, the majority are negative. Of the user acceptability questions; $1-5$ rated at a 6 by $18 \%$ of respondents and question 6 was rated at a 6 by $9 \%$. Nine percent (9\%) rated questions $1-6$ at a 7 for strongly disagree. There was not much difference with the ease of use questions with $9 \%$ of respondents rating questions 7-12 at a 6 and $9 \%$ rating at a 7 for strongly disagree.
Table 1: Age of Respondents.

\begin{tabular}{|c|c|c|}
\hline Age & No. of Respondents & $\begin{array}{c}\text { Percent of Total } \\
\text { Respondents }\end{array}$ \\
\hline $20-30$ years old & 2 & $10.50 \%$ \\
\hline $30-40$ years old & 6 & $31.60 \%$ \\
\hline $40-50$ years old & 4 & $21.10 \%$ \\
\hline $50-60$ years old & 5 & $26.30 \%$ \\
\hline 60 + years old & 1 & $5.30 \%$ \\
\hline Total & 18 & $95 \%$ \\
\hline
\end{tabular}

Table 2: *Represents 11 total respondents.

\begin{tabular}{|c|c|c|c|c|c|c|c|}
\hline \multicolumn{8}{|c|}{ Respondents with no experience using VGo } \\
\hline \multirow{2}{*}{$\begin{array}{l}\text { Percent of Total } \\
\text { Responses* }\end{array}$} & 1 & \multirow{2}{*}{2} & \multirow{2}{*}{3} & 4 & \multirow{2}{*}{5} & \multirow{2}{*}{6} & \multirow{2}{*}{$\begin{array}{c}\text { 7Strongly } \\
\text { disagree }\end{array}$} \\
\hline & Strongly agree & & & Neutral & & & \\
\hline \multicolumn{8}{|c|}{ Question } \\
\hline \multicolumn{8}{|c|}{ User Acceptability } \\
\hline $\begin{array}{l}1 \text { Accomplish } \\
\text { tasks quickly }\end{array}$ & 0 & 0 & 0 & $54.50 \%$ & $18 \%$ & $18 \%$ & $9 \%$ \\
\hline $\begin{array}{l}2 \text { Improve job } \\
\text { performance }\end{array}$ & 0 & 0 & $9 \%$ & $63.60 \%$ & 0 & $18 \%$ & $9 \%$ \\
\hline $\begin{array}{l}3 \text { Increase } \\
\text { productivity }\end{array}$ & 0 & 0 & 0 & $72.70 \%$ & 0 & $18 \%$ & $9 \%$ \\
\hline $\begin{array}{c}4 \text { Enhance } \\
\text { effectiveness }\end{array}$ & 0 & 0 & $9 \%$ & $72.70 \%$ & 0 & $18 \%$ & $9 \%$ \\
\hline $\begin{array}{l}5 \text { Easier to do } \\
\text { job }\end{array}$ & 0 & $9 \%$ & 0 & $54.50 \%$ & $9 \%$ & $18 \%$ & $9 \%$ \\
\hline 6 Useful in job & 0 & 0 & $18 \%$ & $72.70 \%$ & 0 & $9 \%$ & $9 \%$ \\
\hline \multicolumn{8}{|c|}{ Ease of Use } \\
\hline $\begin{array}{l}7 \text { Learning to } \\
\text { operate }\end{array}$ & $9 \%$ & 0 & 0 & $72.70 \%$ & 0 & $9 \%$ & $9 \%$ \\
\hline $\begin{array}{l}8 \text { Easy to do } \\
\text { what I want } \\
\text { it to }\end{array}$ & $9 \%$ & 0 & 0 & $72.70 \%$ & 0 & $9 \%$ & $9 \%$ \\
\hline $\begin{array}{c}9 \text { Clear and } \\
\text { understandable }\end{array}$ & 0 & 0 & 0 & $81.80 \%$ & 0 & $9 \%$ & $9 \%$ \\
\hline 10 Flexible & 0 & 0 & 0 & $81.80 \%$ & 0 & $9 \%$ & $9 \%$ \\
\hline $\begin{array}{c}11 \text { Easy to } \\
\text { become skillful }\end{array}$ & 0 & $9 \%$ & $9 \%$ & $63.60 \%$ & 0 & $9 \%$ & $9 \%$ \\
\hline 12 Easy to use & 0 & 0 & $9 \%$ & $72.70 \%$ & 0 & $9 \%$ & $9 \%$ \\
\hline
\end{tabular}

Table 3: *Represents 8 total respondents.

\begin{tabular}{|c|c|c|c|c|c|c|c|}
\hline \multicolumn{8}{|c|}{ Respondents with Experience Using Vgo } \\
\hline $\begin{array}{l}\text { Percent of Total } \\
\text { Responses* }\end{array}$ & $\begin{array}{l}1 \text { Strongly } \\
\text { agree }\end{array}$ & 2 & 3 & 4 Neutral & 5 & 6 & $\begin{array}{l}7 \text { Strongly } \\
\text { disagree }\end{array}$ \\
\hline \multicolumn{8}{|c|}{ Question } \\
\hline \multicolumn{8}{|c|}{ User acceptability } \\
\hline $\begin{array}{l}1 \text { Accomplish } \\
\text { tasks quickly }\end{array}$ & 0 & $37.50 \%$ & $12.50 \%$ & $37.50 \%$ & 0 & 0 & $12.50 \%$ \\
\hline $\begin{array}{l}2 \text { Improve job } \\
\text { performance }\end{array}$ & 0 & $12.50 \%$ & $25 \%$ & $50 \%$ & 0 & $12.50 \%$ & 0 \\
\hline $\begin{array}{l}3 \text { Increase } \\
\text { productivity }\end{array}$ & 0 & $12.50 \%$ & $50 \%$ & $25 \%$ & 0 & 0 & $12.50 \%$ \\
\hline
\end{tabular}


Current Trends in Biomedical Engineering \& Biosciences

\begin{tabular}{|c|c|c|c|c|c|c|c|}
\hline $\begin{array}{c}4 \text { Enhance } \\
\text { effectiveness }\end{array}$ & 0 & $12.50 \%$ & $25 \%$ & $37.50 \%$ & 0 & $12.50 \%$ & $12.50 \%$ \\
\hline $\begin{array}{l}5 \text { Easier to do } \\
\text { job }\end{array}$ & 0 & $12.50 \%$ & $25 \%$ & $25 \%$ & $12.50 \%$ & $12.50 \%$ & $12.50 \%$ \\
\hline 6 Useful in job & 0 & $37.50 \%$ & $12.50 \%$ & $50 \%$ & 0 & 0 & 0 \\
\hline \multicolumn{8}{|c|}{ Ease of Use } \\
\hline $\begin{array}{l}7 \text { Learning to } \\
\text { operate }\end{array}$ & $12.50 \%$ & 0 & $12.50 \%$ & $62.50 \%$ & $12.50 \%$ & 0 & 0 \\
\hline $\begin{array}{l}8 \text { Easy to do } \\
\text { what I want } \\
\text { it to }\end{array}$ & 0 & $12.50 \%$ & 0 & $62.50 \%$ & $12.50 \%$ & 0 & 0 \\
\hline $\begin{array}{c}9 \text { Clear and } \\
\text { understandable }\end{array}$ & 0 & $12.50 \%$ & $12.50 \%$ & $62.50 \%$ & 0 & $12.50 \%$ & 0 \\
\hline 10 Flexible & 0 & $25 \%$ & $12.50 \%$ & $50 \%$ & 0 & $12.50 \%$ & 0 \\
\hline $\begin{array}{c}11 \text { Easy to } \\
\text { become skillful }\end{array}$ & 0 & 0 & $12.50 \%$ & $75 \%$ & 0 & 0 & $12.50 \%$ \\
\hline 12 Easy to use & 0 & $12.50 \%$ & $25 \%$ & $50 \%$ & $12.50 \%$ & 0 & 0 \\
\hline
\end{tabular}

Table 3 displays the responses to each of the 12 questions from the eight respondents with experience using VGo. The questions are grouped by the user acceptability questions and ease of use questions. For the user acceptability questions the percent of neutral responses range. There are important limitations of the study to be considered. The sample size for the survey was small, and survey conducted for this study was limited to one organization, hence generalizing the data will be difficult. However, the concepts behind the study could apply to evaluation of user acceptance to any type of technology. The survey was limited to one type of telemedicine technology, VGo. Hence, the study is not representative of all available telemedicine technology.

\section{Conclusion}

The results of this survey clearly indicate that there is a difference in user perceived usefulness and ease of use of the telemedicine technology VGo based on the length of experience with the product. In addition, the results of the responses to each question represent the user's perceived usefulness and ease of use of the product. The overall perceptions of the respondents were neutral, but did reveal that that a percentage of respondents perceive that it would not be easy to get VGo to do what they want, that they would not be able to perform tasks more quickly and it would not make their job easier. However, the results also indicated that user's perceived that it would be easy to become skillful at using VGo and that it would be useful in their job.

The results of this study are encouraging as they reveal a more positive perception from staff with experience using the telemedicine product and an overall perception that the product would be useful and easy to become skillful at using. This information demonstrates user acceptance of the product and identifies some of the barriers that the users perceive. Since the more experienced users had more positive response, allowing for more training time for those users with no experience to allow them to become familiar with the product would be beneficial to increasing acceptance. The identified barriers that it would not be easy to get VGo to do what they want, that they would not be able to perform tasks more quickly and it would not make their job easier can be addressed through more rigorous training and hands on experience to alter these perceptions. Improving acceptance and usage of this technology will ultimately improve patient outcomes.

\section{References}

1. Wechsler LR, Tsao JW, Levine SR, Swain-Eng RJ, Adams RJ, et al. (2013) Teleneurology applications: Report of the Telemedicine Work Group of the American Academy of Neurology. Neurology 80(7): 670-676.

2. French B, Day E, Watkins C, McLoughlin A, Fitzgerald J, et al. (2013) The challenges of implementing a telestroke network a systematic review and case study. BMC Medical Informatics and Decision Making, 13: 125 .

3. Freeman WD, Vatz KA, Griggs RC, Pedley T (2013) The workforce task force report clinical implications for neurology. American Academy of Neurology. Neurology (81): 479-486.

4. George BP, Scoglio NJ, Reminick JI, Rajan B, Beck CA, et al. (2012) Telemedicine in leading US neurology departments. The Neurohospitalist 2(4): 123-128.

5. Wechsler LR (2015) Advantages and limitations of teleneurology. JAMA Neurol 72(3): 349-354.

6. Davis LE, Coleman J, Harnar J, King MK (2014) Teleneurology: successful delivery of chronic neurologic care to 354 patients living remotely in a rural state. Telemed J E Health 20(5): 473-477.

7. Ward MM, Ullrich F, MacKinney AC, Bell AL, Shipp S, et al. (2016)Teleemergency utilization: In what clinical situations is tele-emergency activated? J Telemed Telecare 22(1): 25-31. 
This work is licensed under Creative Commons Attribution 4.0 License DOI: $10.19080 /$ CTBEB.2017.04.555642

\section{Your next submission with Juniper Publishers will reach you the below assets}

- Quality Editorial service

- Swift Peer Review

- Reprints availability

- E-prints Service

- Manuscript Podcast for convenient understanding

- Global attainment for your research

- Manuscript accessibility in different formats ( Pdf, E-pub, Full Text, Audio)

- Unceasing customer service

Track the below URL for one-step submission https://juniperpublishers.com/online-submission.php 